\section{Hormone Research}

\section{J.K.H. Wales}

Division of Paediatrics, Sheffield Children's Hospital, Sheffield, UK
Horm Res 1998;50:341

Concerning the Article by Ogata et al. [1]

\title{
Hypergonadotropic Hypogonadism in a 3-Year-Old Girl with Blepharophimosis, Ptosis, and Epicanthus inversus Syndrome
}

In the September issue of Hormone Research, Ogata et al. [1] describe a prepubertal patient with blepharophimosis, ptosis, and epicanthus inversus syndrome (type 1 BPES) with hypergonadotropic hypogonadism. Although the syndrome is subdivided into type 1 with infertility of affected females and type 2 with male and female autosomal dominant transmission, it is not known whether the two forms are allelic variants [2]. Both types are heterogeneous and have been linked to a $3 \mathrm{q} 22-23$ continuous gene deletion with larger deletions having more dysmorphic features, short stature, and mental retardation [2].

Other endocrine abnormalities are not frequent, although the single mesial maxillary tooth that is sometimes associated with growth hormone deficiency and the holoprosencephaly sequence were described by Karimi-Nejad et al. [3] - in that case computed tomography scans of the brain were normal. I here describe an 11.4-year-old male with type 2 BPES probably inherited from his father who presented with a height SD score of -1.52 as compared with a midparental height of +0.4 . The TW2 bone age was 9.5 years. The peak growth hormone level to stimulation was $6.5 \mathrm{mIU} / \mathrm{l}$; normal luteinizing hormone releasing hormone test (luteinizing hormone $0.3,2.1$, and $2.7 \mathrm{mIU} /$ $\mathrm{ml}$ and follicle-stimulating hormone 2.6, 5.6, and $8.3 \mathrm{mIU} / \mathrm{ml}$ at 0,20 , and $60 \mathrm{~min}$, respectively) with a normal thyrotrophin-releasing hormone, prolactin, and cortisol response. Karyotype normal and chromosome 3 normal to detailed banding studies. Magnetic resonance imaging showed hypoplastic anterior pituitary with normal stalk.

Apparently isolated growth hormone deficiency was present in this case of BPES associated with a small pituitary gland and presumably only a small, undetected, gene deletion. Many genes are implicated in normal pituitary development and may be associated with midline facial and eye abnormalities [4]. It is possible that some cases of BPES may have pituitary abnormalities accounting for short stature and that chromosome 3 may be worth searching for further genes related to pituitary development.

\section{References}

1 Ogata T, Hasegawa T, Tamai S, Sato S, Hasegawa Y, Matsuo N: Hypergonadotropic hypogonadism in a 3-year-old girl with blepharophimosis, ptosis, and epicanthus inversus syndrome. Horm Res 1998;50:190-192.

2 On-line Mendelian Inheritance in Man (OMIM). http://www.ncbi.nlm.nih.gov/Omim/

3 Karimi-Nejad A, Karimi-Nejad R, Najafi H, Karimi-Nejad MH: Blepharophimosis syndrome (BPES) and additional abnormalities in a female with a balanced X:3 translocation. Clin Dysmorphol 1996;5:259-261.

4 Dattani MT, Martinez-Barbera J-P, Thomas PQ, Brickman JM, Gupta R, Mårtensson I-L, Toresson H, Fox M, Wales JKH, Hindmarsh PC, Krauss S, Beddington RSP, Robinson ICAF: Mutations in the homeobox gene HESX1/hesx 1 associated with septooptic dysplasia in human and mouse. Nat Genet 1998; 19:125-133.

\section{KARGER}

Fax + 41613061234 E-Mail karger@karger.ch www. karger.com (c) 1998 S. Karger AG, Basel

0301-0163/98/0506-0341\$17.50/0

Accessible online at: http://BioMedNet.com/karger

\author{
Dr. J.K.H. Wales \\ Division of Paediatrics, Sheffield Children's Hospital \\ Sheffield S10 2TH (UK) \\ Tel. +44 114271 7508, Fax +44 1142755364 \\ E-Mail j.k.wales@sheffield.ac.uk
}

